\title{
Defining Secularism in the Particular: Caste and Citizenship in India, 1909-1950
}

\author{
Shabnum Tejani \\ SOAS, University of London
}

\begin{abstract}
Drawing on recent debates on secularism, this article addresses the methodological problem of writing histories of secularism in context. It considers the experience of India. I argue that a study of the issues from which secularism emerged historically offers a way out of the secularism-religion binary which, in India, has obscured contemporary problems related to democracy. These issues had to do with ensuring the public representation of minorities, both religious and caste, regardless of their relative size or social power. Scholarship on the minority question has begun with the constituent assembly and that on secularism centered on the category of religion. In contrast, this article argues that caste was central to the formulation of Indian secularism and requires a longer historical perspective. It maintains that secularism reified the religious minority and, in so doing, denied both its potential to overcome marginality and the legitimacy of the community in the nation.
\end{abstract}

\section{INTRODUCTION}

The so-called "resurgence of religion" in "a secular age" has prompted much consideration of the viability of secularism as a set of political prescriptions and philosophical ideals for the contemporary world. ${ }^{1}$ The set of precepts that called for a separation of the state from religious institutions or "politics" from "religion" that developed in Western Europe and the United States from the 17th century seem anachronistic in the 21 st century. The widespread nature of religious movements across the globe - Christian, Hindu, and Muslim - asserting political ideals and ambitions from India to Morocco to the United States, have challenged what many took to be the necessary historical trajectory of liberalism.

Address correspondence and reprint requests to: Shabnum Tejani, SOAS, University of London, London, United Kingdom. E-mail: st40@ soas.ac.uk 
Secularization as part of a world historical and social process of modernization has not resulted in religion's decline, nor has it "retreated" from the public sphere to take its proper place in the private lives of individuals.

Scholars have long taken for granted that their work is produced and consumed in secular spaces within a rational world: we build arguments on rational investigation and as a result, many of us have found it difficult to account for the affective, "non-rational" motivations of human behavior. Likewise, the organizing framework of international politics has proceeded with the assumption that states are rational actors. It had become common sense that intellectual work and political action grounded in non-secular epistemologies were somehow suspect: the former, seen to be forwarding a particular agenda, was believed incapable of arriving at universal or generalizable conclusions and the latter, in its "unreason," proved an inherently destabilizing and socially divisive force in domestic as well as international arenas. Global religious movements and the assertion of religious identities in liberal democratic societies have implicitly and explicitly brought the assuredness of secular knowledge and secular politics into question and have led scholars to ask if we have now entered a "post-secular" age (Audard, 2011; Habermas, 2008; Pecora, 2006).

In light of secularism's "failure" to domesticate religion, Charles Taylor and Juergen Habermas, among others, have returned to the question of how to resolve the place of religion in the public sphere as part of the "political" in liberal democracies. Philosophers and historians have argued that the normative model of secularism requires redefinition and the categories of "religion" and "politics" unpacking. Secularism, locked in permanent opposition with religion, has been universalized and simultaneously depleted of analytical force. As Talal Asad has shown, religion, politics, and secularism are categories whose meanings are not universal but, rather, are tied to their historical contexts: they are modern categories, yet their staging was not replicated in the same way everywhere (Asad 2003; Jakobsen and Pellegrini, 2008; Mitchell, 2000). It is the elucidation of these contexts and meanings that can better answer why secularism emerged at particular junctures in different societies and disaggregate the binary in which politics and religion have been held. This article extends the conclusions of my earlier work on the historical experience of India as it reflects on some of these recent interventions on secularism (Tejani, 2008).

The late 1980s saw the rapid rise of Hindu nationalism (Hindutva) in India. The success of the Bharatiya Janata Party, the electoral wing of the Hindu right, in the 1989 general elections and the demolition in 1992 by thousands of Hindutva volunteers of the Babri Masjid, a 
mosque built in 1528 in Ayodhya, said to be the birthplace of the Hindu god Ram, shocked the world. Postcolonial India had long been held up as a political success story: the world's largest democracy, whose citizens enjoyed freedom of speech and religious tolerance, it was seen to have escaped the military dictatorships and sectarian conflicts that had been the fate of so many former colonies. The violence of 1992 appeared to many in the Western media as the resurgence of internecine rivalries, evidence that Indians had fallen short in the task of over-writing their "traditional" identities of religion and sect with the "modern" identities of nation, class and occupation. Liberal intellectuals and the Englishlanguage media debated the "crisis" of secularism in India (Basu et al. 1993; Gopal 1993; Tambiah 1998). How to explain the rise of such religious sentiment in a secular state? The debate turned on the binaries of "secularism" and "religion," "modernity" and "tradition." Secularism was a force for good, many argued: it promoted tolerance, acceptance of religious diversity and prescribed a set of values that a liberal democratic society could live by. But there were those who disagreed. Ashis Nandy was an early "post-secularist." Writing on religion and politics in the context of the rise of Hindu nationalism, he categorically rejected secularism as a way to combat the ills of communalism or religious intolerance, arguing that Indians had their own traditions of how to live together that they should look to (Nandy 1988; 1997).

This article examines what the term secularism represented at the point of Indian independence, when it became part of political discourse. There is a story of what secularism signified in India with which we are familiar. A political ideology tied to nationalism, secularism was seen to stand for India's modernity and the peaceful integration of its diverse religious communities. It defined the nature of citizenship in the postcolonial state. Secularism was to be the antidote to religious sectarianism that nationalists such as Jawaharlal Nehru and Sardar Patel believed were the root cause of Partition. In India, the term for the political mobilization of a religious identity is "communalism." Religion would take its place in the private lives of individuals, as it did in any modern society, and secularism would overcome the forces of communalism. ${ }^{2}$

It is widely acknowledged that in public debate, secularism in India remains a simple formulaic assertion against any demonstration of religion however that may be defined or understood (Bhargava 2010). Less religion equals more tolerance. Fewer reservations for minorities mean greater national integration and democracy. This binary opposition has obscured rather than illuminated an understanding of contemporary 
problems related to minorities, democracy and identity. It has, for instance, been unable to examine the representation of the cultural rights of Indian Muslims other than letting them be decided by a panel of conservative judges as in the case of Shah Bano in 1985. Neither has it been able to address the violent attacks against Christian communities and their forcible "reconversion" to Hinduism by Hindu nationalists in Gujarat, Madhya Pradesh, and Orissa from 1998, nor account for the pervasive anti-Muslim and anti-low caste sentiment among India's middle classes in relation to policies for reservations in education and employment, other than by asserting that these are forces of tradition and narrow-mindedness which have no place in a modern society. ${ }^{3}$

I argue here that a study of the range of issues from which secularism emerged historically offers a different avenue to understand its meaning in India. These issues had, from the early 20th century, to do with ensuring the public representation of minorities, both religious and caste, regardless of their relative size or social power. Representation was measured through reservations in public institutions such as the army and civil service as well as in schools and universities. Places for minorities were also reserved in regional legislatures as well as central political bodies, often through separate electorates, which were to ensure that in matters of politics and policy, a plurality of interests and voices may be heard. Secularism was not used to describe these measures. On the contrary, there was a great deal of opposition to them particularly from self-styled nationalists of the Indian National Congress, arguably the "liberal" or "mainstream" anti-colonial platform, and the Hindu Mahasabha, a right-leaning organization that forwarded a majority Hindu, anti-Muslim agenda, on the grounds that they fuelled "communal" and "anti-national" sentiment among such communities.

It is significant that the term "secularism" was not widely used in Indian political discourse until the transition to independence. Historically, the colonial state had not remained separate from religious communities: it intervened in disputes, legislated on custom and managed, and taxed religious institutions that were under its jurisdiction. Its rhetoric was not a separation of religious and political institutions but of "non-interference" in the customs and traditions of Indians. It sought to stand as a neutral adjudicator, to uphold rather than alter traditions. However, as many have argued, the state legislated on, and altered customs in many contexts in a myriad of different ways (Bhattacharya 1996; Carroll, 1983, Appadurai 1981). Nevertheless, for our purposes, the important point is this: if one takes secularism to mean the separation of the state from 
religious institutions, neither was the term used, nor was it practiced in colonial India. There was no history of secularism in India before independence. India's postcolonial state continued the practice of its predecessor, seeking a position of "equidistance" from religious institutions rather than separation from them (Luthera 1964; Smith 1963). Or as Rajeev Bhargava has recently argued, it sought to maintain a position of "principled distance" (Bhargava 2010).

This article outlines the debates on the minority or communal questions from the early 20th century up to independence. It argues that secularism in India emerged as a category in relation to these debates; indeed, that secularism was defined against these earlier attempts to balance the rights and entitlements of communities as such. There were important continuities with the colonial period: secularism after independence signified all that nationalism had before - a unifying ideal opposed to the politics of "communalism." "Communalism," by 1930, had become associated with the assertions of religious minorities, particularly Muslims, for political and, in some cases, territorial recognition: guaranteed representation in legislatures and the grouping of provinces with Muslim majorities in the north-west of the subcontinent.

There were also significant departures from the past. Until the constituent assembly (1946-1950), the claims of minorities, both religious and caste, had been considered together. By the time the constitution was ratified in 1950, these claims had been separated. Reservations for religious minorities were abandoned altogether on the basis that their interests would be protected in India's secular state; those for the Untouchables and "tribal" communities, now known as the Scheduled Castes and Scheduled Tribes, were retained for a limited period until these communities were deemed to have reached a level where they no longer required support (Bajpai 2010, chs. 2 and 4; Jha 2002; Tejani 2008, ch. 6). ${ }^{4}$ The representation of a plurality of voices and communities was no longer enough to justify the continued existence of reservations.

The Constituent Assembly Debates (1946-1950) have been the subject of scholarly scrutiny in relation to secularism and the representation of minorities (Ansari 1999; Bajpai 2010; Chiriyankandath 2000; Copland 2010; Jha 2002). On minority representation, some have argued that the elimination of reservations for religious minorities represented an attenuation of their rights (Ansari 1999; Bajpai 2010). In the discussions on secularism, this scholarship has retained its focus on religion. To elaborate the meanings of secularism in the Indian context, scholars have tended to take a normative view of what constitutes its practice, namely, the 
separation of political from religious institutions and the protection of religious minorities. Secularism's meaning, in public debate and in scholarship, remains fundamentally about religion (Copland 2010; Jha 2002; Chiriyankandath 2000). For instance, Shefali Jha's examination of secularism traces the way the debate unfolded in the constituent assembly. She examines its main themes: safeguards for religious minorities, religious education in government schools, and the uniform civil code. But in so doing, her analysis remains within the bounds of the debates itself and reproduces a meaning for secularism in India as necessarily tied to religion. Bajpai, in contrast, argues that secularism was one of a series of overlapping concepts - democracy, social justice, development, and national unity - which laid the conceptual framework for how the minority question would be resolved (Bajpai 2010, chs. 3 and 4).

I depart from this literature when it comes to the particular way in which secularism was defined in this context. If we are to develop an understanding of secularism at the point it entered public political debate in India, we have to shift our perspective away from religion and make caste central to our analysis. ${ }^{5}$ Like Bajpai, I have argued that secularism was a relational category that emerged at the nexus of nationalism and democracy (Tejani $2008,14-15)$. But central to the formulation of India's democracy were the Scheduled Castes. India's secularism was defined around the fate of the Scheduled Castes. Where Bajpai has argued that the separation of religious and caste reservations led to the narrowing of the rights of religious minorities, I would take this further to say that it was through this very separation that Indian secularism was defined.

This article unfolds in three parts. The first outlines the main debates on secularism in India. The second examines the shifting philosophical underpinnings of holding minor communities apart by their recognition through reservations from the first instance of their introduction in 1909 through the Communal Award in 1932 to the final ratification of the constitution in 1950. The final section turns to a consideration of recent debates on secularism more broadly with a view to seeing how far the historical experience of India allows us to reflect on and redefine the category of secularism for these times.

\section{DEBATE ON SECULARISM IN INDIA}

There are four distinct strands to the debate on secularism in India. First, the liberal left position that religion and politics belong in different 
spheres. This position saw the rise of Hindutva in the 1980s as representing a crisis of the secular state. Religion had not taken its place in the private sphere, and it was the attachment of Indians to their primordial identities that had prevented the emergence of a civic ideal. For the proponents of this position, secularism represented the "operation of scientific temper and rationality" (Verma 1990). Not all defenders of secularism embraced the modernization model. Some argued that it was not solely a western concept, but in fact has a long history in India (Puri 1990). In India, the argument goes, secularism was not understood in terms of the separation of religion and politics but as "tolerance." This is a civilizational argument which maintains that Indian "culture" has, since ancient times, accommodated many different peoples. Hindu dharma, with its loose structure, was able to draw into its ambit the mores of these different people because it held within it an indigenous concept of secularism, sarva dharma samabhava, the idea that all religions are true. ${ }^{6}$ Gandhi, most famously, argued that tolerance and the accommodation of difference was an inherent characteristic of Indian culture (Parekh 1989, ch. 4).

Second is the argument that secularism has no place in India. This is represented by those such as T.N. Madan and Ashis Nandy. Madan, in his much-cited piece "Secularism in its Place," argued that privatization of religion was a product of late Christianity but the Indian religions of Islam, Hinduism, Buddhism, and Sikhism have no history of a Reformation and thus no prescription for the separation of secular and sacred spheres (Madan 1987 [1998]). Secularism was thus a "borrowed idea" in India, at odds in a society whose very fabric was religious. Yet, in the face of what he calls the "recrudescence of religious fanaticism," intellectuals continued to see secularism as "the sole and adequate remedy" against communalism. They underestimated the fact that "religion itself could be a powerful resource in the struggle against religious extremism" (Madan 1998, 308). Madan suggested that those who understood religion as mere superstition should take home-grown traditions seriously. Ashis Nandy is a similarly ardent critic (Nandy 1988 [1998]). South Asian cultures live with "fluid definitions of the self," which are fundamentally incompatible with secularism's ideologies of progress and modernization, he maintains. The attempt to create public and private identities - to persuade Indians to see themselves as Indians first and Muslims, or Sikhs second - has little meaning in India. Madan and Nandy argue that Indian culture has its own methods of dealing with religious intolerance that people can draw on. Rejecting 
the legitimacy of secularism altogether, Nandy argues that in India, secularism can never be anything more than an "imperialism of categories" (Nandy 1998, 321).

Madan and Nandy are both astute critics of liberal secularism. Each sees it as an imposition of a world view incompatible with the epistemologies of India. However, in depicting Indian society as "traditional," as against the creeping and pernicious modernization of the West, each essentializes an idea of "tradition." And, in their search for indigenous answers to the problems of sectarianism, they see Indian modes of tolerance as stemming from what can broadly be called Hindu civilization. In this sense, as Sumit Sarkar has argued, this position shares discursive ground with the Hindu right (Sarkar 1994).

The third strand is the position represented by the Hindu right. This holds that any recognition of minorities, specifically Muslims, is "pseudo-secularism" (Talreja 1996). This was the charge Hindu nationalists brought against the Congress. They argued that this so-called secular party was bringing religion into politics. Reservations for minorities in public institutions and the continued support of a separate civil law for Muslims were examples brought as evidence of such pseudo-secularism. This position maintains that a genuinely secular state would not recognize any difference among its citizens, that it would treat each as equal before the law. However, its reactionary nature comes from its determined claims that the majority population, and therefore the norm of civic culture, is Hindu. This shares with the first position the idea that over thousands of years, migrants, traders, and warriors came to India and became Indian. Where it diverges is that the accommodative nature of Hindu dharma is seen as a weakness rather than strength. The characteristic "tolerance" of Indian civilization is represented as a tragic naïve innocence that resulted in Indians falling before the proselytizing religions of Islam and Christianity. At the same time, the qualities of this dharmic universalism left nobody untouched. Converts to other religions remained in essence Hindu, since it was from the same racial and cultural stock that all had emerged.

The fourth position is represented by Rajeev Bhargava. Secularism in India has been understood as a "doctrine with a fixed content," its rich and varied history has been reduced "to a dead and monotonously repeated formula" which "mechanically separates religion from the state ... foolishly innocent of its ties with substantive values," he argues (Bhargava 2007, 22-24). Bhargava's point is that in India, secularism had certain underlying meanings which developed historically but 
which have been forgotten and need to be recovered. In looking to this history, Bhargava turns to the constitution which provides for state intervention in religious affairs. Article 25(2)(b), for instance, allows the state to intervene in the activities of Hindu religious institutions on the grounds of social welfare and reform: it can require temples to be opened "to all classes and sections of Hindus" (Bhargava 2007, 35). Article 17 abolished Untouchability, a central feature of the caste system and Hinduism. While these provisions do not reflect a strict institutional separation from religion, Bhargava maintains they were progressive measures which sought to enhance the democratic nature of the state without undermining secularism (Bhargava 2007, 41). Indeed, he goes on, Western theories have treated secularism as a "single-value doctrine": separation "for the sake of the fullest possible liberties of individuals including their religious liberty." In India, it was a "multi-value doctrine." It sought to promote the liberal ideal of tolerance, but further values became associated with it because of the way in which secularism was tied closely with democratic and nationalist ideals, particularly "citizenship rights, including the rights of religious minorities" (Bhargava 2007, 47). What made Indian secularism distinctive in Bhargava's view, was the state's position of "principled distance" - it interfered as necessary to uphold the rights of communities - an approach that had its own history in India.

Madan and Nandy's wholesale rejection of secularism comes out of what they see as its failure to provide a basis for communal harmony and integration in India. The position of the Hindu right seeks to enforce a strict secularism where no recognition of group rights exists at all. Bhargava, in the face of the "crisis" in Indian secularism, wants to recover a distinctive meaning for it, there is too much at stake politically to abandon secularism, he says. Each of these positions critiques the normative model and each re-inscribes a separate meaning for the term. The "many meanings" of secularism amply demonstrates that a stable, universal meaning for the idea can no longer be taken for granted. Yet it also allows wildly contradictory political positions to exist on a level with each other and can dissolve into an uncritical relativism. As an "empty" category devoid of inherent meaning, it has been open to appropriation in sometimes cynical ways.

Partha Chatterjee, Neera Chandhoke, and Aditya Nigam have all acknowledged this ambivalence and outline the problems that the secularism-religion binary had led to (Chandhoke 1999; Chatterjee 1994; Nigam 2006). However, rather than evolving new meanings, each examines what secularism has meant in the different circumstances of its contestation. In 
their own ways, they argue that secularism in India has less to do with defining the contours whereby the state may or may not intervene in religious affairs, or the degree of religiosity of the population itself. Instead, it is related to what the recognition of difference - of minority communities - means for the formulation of a national community within the framework of liberalism. Chandhoke, for instance, contends that secularism in India represented a democratic ethos, but one that expressed itself in the language of religion. Thus, it was not about finding the right place for religion per se, but ensuring the rights of minorities. This resonates with Bhargava's and Bajpai's positions outlined earlier, and, in its emphasis on secularism as part of Indian liberalism, with my own. But Bhargava, Bajpai, Chandhoke, and others begin at the point of independence. I want to take a longer historical perspective that begins in the early twentieth century and draws in the problem of caste.

\section{HISTORIES OF REPRESENTATION}

\section{Separate Electorates, 1909}

In 1906, the government of India began considering constitutional reform. A deputation of prominent Muslims had visited the Viceroy, Lord Minto, in October of the same year, to argue that in any such reform, Muslims should, on account of their status as a minority in India and their historical significance to Indian society, be considered an electoral category in their own right. Colonial officials agreed. Their agenda for introducing reforms at this moment was two-fold: first, to provide a counter to what they saw as the "growth of a sentiment of nationality" as witnessed in the political agitation against the partition of Bengal in 1905, initiated largely by Western educated Brahmins. Morley, the Secretary of State for India, believed that alongside this growing "nationality" existed "a great body of conservative opinion," men who were loyal to government. These were the landlords, the "great agricultural classes," who would provide stability in the winds of change, and it was they who should be made central to any political reform. ${ }^{7}$ Second, the reforms were a gesture toward Indian liberals who had pushed for greater representation on executive and legislative bodies.

Officials insisted, however, that the reforms had to be "appropriate": they had to reflect "the actual distribution of power in society" rather than seek to change it, noted Theodore Morison, an advisor on council 
reform. ${ }^{8}$ Earlier reforms in 1892 had resulted in members of the urban professional classes, representing a tiny sliver of society, coming to the fore. Rural interests, such as those of the big landlords, as well as Muslims, had gone almost completely without representation. While the professional classes were certainly best able to compete, they had been disproportionately successful and the results did not reflect the character of Indian society. Minto maintained it was their responsibility to structure a system that would fairly represent and draw into formal politics a wider array of social groups than currently existed. The 1892 reforms were thought to have failed because they had been based on territorial rather than communal representation. They were Minto felt, "a western importation uncongenial to Eastern tastes."9

European orientalists and colonial officials had long understood Indian society as comprised of communities - of sect, caste, and religion - rather than individuals. These were the "natural compartments" of society and could provide the foundation for a system where the principle of territorial voting had not. These compartments extended to other non-confessional interests: landholding, commercial, educational as well as religious. The reforms would be an attempt to balance these interests. There were contradictions inherent in this approach. Minto noted that by bringing communal groups to the forefront, the reforms marked "a complete departure from our attitude of neutrality as between races and sects." But he justified this on the grounds that the rigidity of India's communities meant that they "can be represented in the fullest sense of the word only by persons who actually belong to them." 10 Significantly, the idea of balancing interests implied a certain parity among them. So, while Hindus were a numerical majority across India, reforms were bound to represent communities' interests in roughly equal ways.

Communal bodies to be represented in the imperial legislative councils for non-official members included the professional middle class, landholders, Muslims, European commerce, and Indian commerce. A small number were also reserved for "minorities, special interest, or experts." Provincial councils in the Bombay, Bengal, and Madras presidencies and the United Provinces would have seats reserved in such a way as to reflect the communal interests in each region. In the Bombay Presidency, for instance, they were: municipalities and district boards, the presidency corporation, the university, landholders, Muslims, the Bombay and Karachi Chambers of Commerce, mill owners associations for Bombay and Karachi and the Indian commercial community. ${ }^{11}$ 
These communal bodies would have a separate electorate, that is, a representative taken from within the group who was elected or nominated only by members of the group itself. Fearing that this would isolate communities from participating in, and eventually merging with, the wider "general" electorate, Minto proposed these communities would have a "double vote" - they would cast their vote in a joint as well as a separate electorate.

Communities that had been given separate recognition in councils welcomed the measures, although some argued they did not go far enough. However, the urban professional class, the majority of whom were upper-caste and Western educated, were vehemently opposed, arguing that the reforms were "medieval," "denationalizing" and evidence of an imperial conspiracy of divide and rule. The government had abandoned its policy of non-interference, many argued, and was now showing blatant partisan behavior. The Bombay Presidency Association contended that these reforms should reward merit, they should "enable the Government to secure the benefit of the knowledge, experience, advice and cooperation of the most capable and the best trusted representation of all classes and interests." 12 It was widely held that if Muslims had not taken advantage of the opportunities afforded to them by colonial rule, they had "only themselves to blame for the consequences of their neglect."13 The separate electorate for Muslims, rather than landholder and commercial groups, caused the greatest alarm as it was seen to introduce religion into politics: "the State should not penalize political opinions and favour religious beliefs. British rule in India will be deprived of one of its most potent justifications if it ceased to exercise a unifying influence on the heterogeneous people of the country. The ideals it is bound to keep before it are modern, not medieval." 14

Despite continued opposition, separate electorates with supplementary participation in joint electorates were introduced for communal bodies. Officials of the government tried to appease concerns saying that the measures were temporary. Significantly, the reforms created Muslims as a separate political category. Equally important was the justification for this measure: the separate electorate became seen as the way to educate socially and politically "backward" communities in the ways of liberal democracy, to protect their identities and personalities as they were integrated into a larger representative framework and to ensure that they reflected the plural communal landscape of India. The separate electorate would shape all future attempts to address the place of the minority community in the nation. ${ }^{15}$ 


\section{Ambedkar and a Proposal for Separate Electorates for Untouchables, 1919}

After the First World War, came the second round of constitutional reforms in which B.R. Ambedkar made the argument for separate electorates for Untouchables. ${ }^{16}$ Ambedkar, deeply critical of Congress' and Gandhi's approach to Untouchable reform, would become the foremost advocate of Untouchable rights. He argued strongly that social reform as advocated by upper-caste reformers, including Gandhi, would never be adequate to lift the depressed classes out of their historically marginalized state to join society as equal citizens. ${ }^{17}$ Rather, in line with arguments forwarded for separate communal electorates in 1909, Ambedkar maintained that Untouchables should be considered a minority in their own right and enjoy the protection that came with such recognition. India, he said, was a society fundamentally divided by communities isolated from one another. Unlike other societies which overcame divisions through fluid interaction between different groups, India was divided by religion and, most profoundly, by caste where the greatest divide lay between "touchables" and Untouchables (Ambedkar 1989, 247-249). He warned that it would do no good to ignore these if representative politics had any hope of being democratic and popular. Territorial constituencies would be inappropriate as they had so proved for other communal bodies, for they were properly representative only of material interests. The injustice that would be committed by instituting territorial elections would be that while "it may not leave unrepresented the interests of the members of the minor groups, [it] leaves them without any chance of personal representation" (Ambedkar 1989, 251).

Territorial constituencies, unable to guarantee a voice for the interests of minor communities, failed to create a genuinely representative government. Instead, Ambedkar favored proportional representation for Untouchables in the different regions and separate communal electorates as a way to achieve this. He remarked that liberal democracies made no provision for communal representation on the grounds that they were seen to forward particular social agendas over the unity of the nation. However, the premise of this position was that the social and the political could be easily separated, that Untouchability was an issue for reformers and constitutionalism a political concern. But the social and the political were inseparable and could not be "worn one at a time as the season demands." Open competition "is as it should be if all were equally free to fight," but "to educate untouchables by Shahtras [sic] into pro- 
touchables and the untouchables into anti-untouchables and then to propose that the two should fight out at an open poll is to betray signs of mental aberration or a mentality fed on cunning" (Ambedkar 1989, 263). ${ }^{18}$ Indeed, it was this approach that would tend to "develop the personality of the few at the cost of the many" (Ambedkar 1989, 251). Ambedkar recommended in 1919 that Untouchables be allowed to elect their own representatives but it was not to be. The Southborough Committee decided against on the basis that they were not educated enough to provide an electorate. Instead, representatives would be nominated to the provinces.

\section{A Minorities Pact, London, 1932}

Ambedkar took these arguments forward to the Round Table Conferences in London in 1931. These meetings were called to formulate a constitution for a future independent India. Previous attempts in 1928 had foundered around the issue of communal representation (All Parties Conference, 1928). Ambedkar took his place alongside a range of other representatives of minority communities: Indian Christians, Sikhs, Muslims, and European commercial bodies, all of whom maintained that the constitution should recognize minority communities through reservations and so legitimize their place in the nation.

Gandhi, as the representative of the Congress, articulated the opposition that the Congress, Hindu Mahasabha, and Indian Liberals among others shared: the communal or minority question had nothing to do with nationalism but was a problem for nationalism to overcome. Moreover, constitution-making did not have to wait for the communal question to be resolved: "solution or settlement of [the] communal problem should not be a condition precedent [on] or a bar to the settlement of purely constitutional issues. If we fail utterly to come to [a] communal settlement still constitution-making must go on and should not be impeded in any way by anybody." 19 Gandhi was ever optimistic about what independence would bring: "I have not a shadow of a doubt that the iceberg of communal differences will melt under the warmth of the sun of freedom." Soon enough, Congress would be recognized as the wholly representative body that it was. It would, along with upper-castes, work to bring down the terrible institution of Untouchability but through social amelioration rather than political intervention: "[the Depressed Classes] need protection from social and religious persecution [rather] than election to 
legislatures." ${ }^{20}$ Representatives of minority communities disagreed. For them the constitutional and communal questions were inextricably linked and it was their very citizenship in India that was at stake. The Minorities Pact presented their demands: separate electorates for all.

The Round Table Conferences broke down around this. When the Labour Prime Minister Ramsay Macdonald returned in 1932 with his solution in the form of the Communal Award which granted separate electorates to all the minorities in question, there was a huge outcry. The main opposition settled around Untouchables. Gandhi went on his famous "fast unto death" in protest of what he called a "vivisection" of Hinduism, and others argued that if Untouchables were seen as a separate community, India would be rendered a nation of minorities. A liberal democracy required a national majority, which until now had been the broadly-defined community of Hindus. Enough pressure was placed on Ambedkar that he retracted his position. It was agreed that there would be reservations for Untouchables in legislatures but no separate electorate: Ambedkar was roundly defeated (Kumar 1985). The question of what provisions would be made for communal minorities was again on hold until it had finally to be resolved at the constituent assembly.

\section{Religion, Caste and Citizenship at the Constituent Assembly, 1946-1950}

The purpose of reservations for minorities in late colonial India was seen to have been two-fold. First, to achieve a fair and accurate representation of voices of "major" and "minor" communities in a society that was understood to be constituted by its communities. Second, they were seen to have an educative role: to draw communities considered socially and educationally "backward" - whose participation in institutions of political representation had hitherto been marginal — into the fray. Reservations were seen as a way of overcoming such "backwardness" and thus widening the nascent democratic process. The provisions that emerged from the constituent assembly for minority provision represented a significant break with this longer history.

India's constitution enshrined the values of liberalism. The Objectives Resolution adopted in January 1947 envisioned a constitution that:

guaranteed and secured to all people equality of status, of opportunity, and before the law, freedom of thought, expression, belief, faith, worship, vocation, association and action, subject to law and public morality; and wherein 
adequate safeguards shall be provided for minorities, backward and tribal areas, and depressed and other backward classes (Shiva Rao 1967, 61). ${ }^{21}$

The rights relating to religion had to do with the guarantee of the freedom of conscience, religious worship and the freedom to profess religion subject to public order, and morality. That minorities - linguistic, cultural, religious, and political - should be protected was never at issue. The most pressing question in terms of the promise of safeguards for minorities and backward classes was who precisely constituted these populations, and what the nature of this protection should be. An Advisory Committee on minorities was set up to deal with these questions.

The assembly agreed very early on to abolish separate electorates: they were seen to have heightened rather than diminished communal differences and were an obstacle to national unity. Pandit Govind Ballabh Pant, a member of the Congress Working Committee, argued that Indians had now to think in terms of individual citizenship rather than their affiliation to a community ( $C A D$, vol. II, 310-312). It would be "suicidal" for minorities themselves if separate electorates were upheld, he said ( $C A D$, vol. V, 222-224). Instead, reservation quotas in joint electorates were to be introduced in legislatures as well as a range of public institutions. Significantly, the criteria had yet to be determined for what constituted minority status. What was recognition as a minority meant to achieve?

An advocate for adivasis (indigenous, "tribal" communities) from Bihar argued that to be categorized as a "minority" diminished their significance. Adivasis were "the original owners of this country" and could "never be considered a minority" (CAD, vol. V, 209). However, for Scheduled Castes, recognition as a minority was crucial. One Scheduled Caste Congress representative from Madras argued that separate minority status was important if they were to resist attempts to appropriate them into the Hindu or Muslim community (CAD, vol. V, 206-207).

There remained considerable opposition to reservations even in joint electorates. But whatever disputes existed around the nature or proportion of recognition, that Muslims, Sikhs, Christians, and Anglo-Indians were minorities was not in question. It was on the Scheduled Castes that the discussion turned. That they should be considered a minority made many uneasy: they were, by rights, Hindus. K.M. Munshi, for instance, argued that to extend the term "minority" to include the Scheduled Castes was "a very mischievous extension." They were "part and parcel of [the] Hindu community, and the safeguards are given to them to 
protect their rights only till [sic] they are completely absorbed into the Hindu community" (CAD, vol. V, 227). Others argued that if Scheduled Castes were made a category in their own right, then together with Muslims, they would comprise almost half the population, after which there would be reservations for Christians, Sikhs, Buddhists, and others, leaving Hindus a minority without any influence. This was not democracy as it was commonly understood (CAD, vol. VI, August 28, 1947, 255). Many argued that the only defense for reservations was that they would uplift the backward classes. For Nehru, reservations were part of the "duty and responsibility of the majority" (CAD, vol. VII, November 8, 1948 , 323). That the issue of minority representation turned on the Scheduled Castes rather than Muslims is perhaps surprising. But the way these disenfranchised castes were to be classified - as communities in their own right, or a socio-economic grouping temporarily in need of support to integrate them as citizens in India's new democracy - would provide the justification for how the policy on reservations would unfold.

\section{Secularism}

The discussion on secularism in the assembly rested on the importance of delineating domestic and civic spheres. In many ways, it reflected a normative meaning for secularism. The practice of religion, it was agreed, would be a private concern and thus outside the jurisdiction of the state. Moreover, religious institutions would not receive state patronage. However, the state retained the right to regulate the "secular" activities of religious institutions. Thus, the question of whether a secular state should be able to tax religious buildings, if it had the jurisdiction to order that a temple serving high caste communities should be open to all, whether Muslims in a sabil (a public drinking fountain) could be allowed to restrict water to non-Muslims and if state-funded schools should include religious instruction in their curricula, all featured in the consideration of the nature and structure of the Indian secular state. ${ }^{22}$

The protection of the fundamental rights of minorities was closely woven into this discussion. There were those who argued that protection for a group violated the principles of a secular state $(C A D$, vol. VII, November 9, 1948, 362). Others, Muslim, and Sikh representatives in particular, maintained that their protection had to be explicitly written into the constitution. Moreover, Muslims argued that personal law must be recognized: "in a secular State, citizens belonging to different communities 
must have the freedom to practice their own religion, observe their own life, and their personal laws should be applied to them" (CAD, vol. VII, 544). However, others opposed personal law precisely on the grounds that religious practice was a private affair. "Religion," K.M. Munshi stated in his defense of a uniform civil code, "must be restricted to spheres which legitimately appertain to religion, and the rest of life must be regulated ... in such a manner that we may evolve ... a strong and consolidated nation" (CAD, vol. VII, 547-548).

In April 1947, the advisory committee on minorities recommended that there should be reservations in joint electorates for minorities for 10 years. However, independence had a significant bearing on this agreement and the debate on secularism. From 1920, the constitutional discussions around protection of communal and minority interests comprised both caste and religion. Independence and partition seemed to answer the communal problem - partition created the state of Pakistan, the ostensible home for India's Muslims, and independence created a democratic secular republic for India where minorities would be protected. Thus, after 1947, the purpose of reservations changed. If the secular state ensured freedom of religion and the protection of religious minorities, reservations would bring a measure of equality of opportunity for the disenfranchised classes, the Scheduled Castes and Scheduled Tribes. ${ }^{23}$

In 1948, a sub-committee revised the provisions for reservations determining that they would exist now only for "any backward classes who in the opinion of the State are not adequately represented in the public services" (Shiva Rao 1967, 296). Muslim, Sikh, and Christian representatives in the assembly all made the argument that their communities should be classified as "backward" on the basis that they were also underrepresented in the services and politically marginalized. But in 1949 the sub-committee decided that "it was no longer appropriate in the context of free India and of present conditions that there should be reservations of seats for Muslims, Christians, Sikhs or any other religious minority" (CAD, vol. VIII, Appendix A, May 11, 1949, 311). Instead, it was agreed that "the peculiar position of the Scheduled Castes would make it necessary to give them reservations for a period of 10 years as originally decided" (CAD, vol. VIII, 311). Thus, reservations for religious minorities were withdrawn.

Jha sees this as a failure of the representative system. Why, she asks, could "secular democracy" be used to deny representative safeguards to religious minorities while protecting cultural, linguistic and, I would add, caste, minorities (Jha 2003, 1580)? Bajpai argues that a "legitimating vocabulary" of liberalism was well-established by this period and 
precluded reservations on the basis of religion (Bajpai 2010, 167). A liberal democracy, by definition, could only accommodate difference for the socio-economically "backward." Thus, arguments made by Muslims in the constituent assembly asserting that they too were "backward" were dismissed (Shiva Rao 1967, vol. II, 693; Tejani 2008, 255). The power that a recognition of "backwardness" had, then, was to enable the continuation of constitutional recognition of one set of minorities and not another.

Bajpai has argued that the "nationalist resolution of the minority question" came with this separation of "backward class" from "religious minority" for reservations and safeguards. She maintains that this was an outcome of the particular moment (Bajpai 2010, ch. 4). However, historically, the premise of reservations for minorities was that they would allow communities to overcome their condition of "backwardness." In 1909, if we recall, the separate electorate for Muslims was deemed a temporary measure precisely for this reason. Indian secularism identified religious minorities to protect. However, by not allowing the recognition of "backwardness," secularism essentialized the "religious community," thus removing the dynamic possibilities that such recognition might have brought. It was this reified category of religion that forged a meaning for secularism in postcolonial India.

\section{CONCLUSIONS: REDEFINING SECULARISM IN A POST- SECULAR AGE}

Secularism is a term that stands in for an approach to a world uninformed by, although not necessarily extinguished of, religious faith, one that embraces a worldly ethics and rational thought rather than belief in a divine law of reward and punishment. Necessarily embedded in its meaning is a relationship to "religion." "Religion," often stands in for "tradition," reflecting a personal attachment to ascriptive social identities as well as to belief in a social order founded on hierarchy and informed by faith in the supernatural. Yet, as scholars have long argued, religion is a category that emerged in early modern Europe at the very point at which it became possible to conceive of a world moved by nature rather than a divine power. It is at this point that religion could be seen as one set of human practices among many (Asad 2003, Introduction; Calhoun et al. 2011, 6). The term given to this process of social differentiation of spheres is secularization. However, rather than a natural and progressive 
distancing of the modern secular world from its traditional, divinelyinformed precursor, scholars such as Talal Asad have pointed out that "religion" is a particularly modern category defined through and by the "secular": the two were inextricably interlinked and mutually self-defining. To argue that the categories of religion and secularism were defined in a particular historical context explicitly denies the universality of the secularization thesis. ${ }^{24}$ Asad maintains that their historical specificity meant that these categories, as part of a project of modernity, had "specific practical tasks" within a given society (Asad 2003, 183).

Such an insight shifts the possibilities for studies of secularism from sociological process to historical genealogy. The secularism-religion binary that has framed debates on studies of religion in the public sphere across the globe has circumscribed the terrain within the bounds of its own categories. As Jose Casanova has argued, the fundamental problem with normative secularism is that it "entails a theory of what "religion' is or does." It assumes that "religion" can exist in the abstract, as "a thing that has an essence or that produces certain particular and predictable effects" (Casanova 2011, 66). Thus, religion is "intolerant" and "causes conflict," where secularism overcomes such conflict through "tolerance" (Calhoun 2011, 69). Genealogies allow us to pry apart this "clash of civilizations" approach to understanding religious violence. Historical case studies can elaborate how and why these categories developed and what they meant in relation to political ideologies and social customs: it can elaborate, in Asad's terms, their "tasks" in particular contexts. This can allow us to explore why religion still seems to matter in a secular age.

Taylor has pointed out that we need a radical redefinition of secularism (Taylor 2011a). He argues that scholars dealing with issues of religion and society "have the wrong model" of secularism: "We think that secularism (laicité) has to do with the relationship of the state and religion; whereas in fact it has to do with the (correct) response of the democratic state to diversity" (Taylor 2011a, 36). It is the fixation on religion, Taylor argues, which obfuscates a proper study of secularism in different contexts. The reason that religion has taken center-stage in discussions on secularism has to do with the focus on institutional arrangements - the separation of Church and State or the privatization of religion. But, he maintains, these arrangements were themselves particular responses to historical situations. They were devised to manage grassroots protests and sectarian crises against the entrenched power of various Churches in early modern Europe.

Taylor's study of secularism centers on Latin Christendom in the North Atlantic world from 1500. He argues that a range of scientific, 
philosophical, religious, and political developments from this period created a world where it became possible not to believe in God. Indeed, "faith, even for the staunchest believer" was simply "one human possibility among others" (Taylor 2007, 3). People in the West now live and make sense of their world in what he calls an "immanent frame," the tangible, knowable world around them. Taylor argues powerfully that the history of secularism in the different societies of Western Europe varied according to what the particular negotiations between the different Churches and states were meant to achieve in each context. For instance, in England, secularism emerged as a counter to religious sectarianism, to create "tolerance" and protect a variety of religious beliefs and practices (Mendus 1988). Thus, "secularism" had a different history in the United States than it did in France, England, or Scandinavia and meant something different in each place (Taylor 2011b).

However, Taylor maintains that as an understanding of the specificity of historical experience receded, a focus on form rather than value has won out. The separation of religion and politics is a mantra of secularism's proponents. In contemporary liberal societies, the goals have been defined around the "master formula" of the institutional separation of religious and political spheres whereas it should be the other way around: "one should start from the goals and derive the concrete arrangements from these" (Taylor 2011a, 41). The institutional formula represents one set of solutions to one set of problems of religion in the public sphere: there could be other solutions to other problems. Rather than a bulwark against religion, secular states should be "good faith" attempts to achieve three or four basic goals in a liberal society for which a concern with religion would have little or no necessary place: first, to protect people's right to belong to and practice a particular outlook; second, equal treatment whatever that outlook may be; and third, an equal hearing. Religious viewpoints are no more valid than non-religious and atheistic positions in this (Taylor 2011a, 56).

Taylor is acutely attuned to the complexities of the North Atlantic experience with religion. Yet, his argument that "secularity" is the product of a history of reform and innovation in the European Christian world remains circumscribed in significant ways. Saba Mahmood, for instance, has questioned the reach of Taylor's argument, noting that the focus on the "North Atlantic" presumes a cultural uniformity based on Latin Christendom (Mahmood 2011). Limiting the study to Western Christianity does not simply limit the amount of data to analyze but has methodological implications for the very understanding of "religion" 
and modernity. Not only does Taylor too easily overlook the world beyond the West, he fails to account for the ways in which the internal others (Jews, Muslims) of the North Atlantic world had a constitutive impact on religious thought and practice itself (Mahmood 2011, 289-293). Taylor is thus unable to ask the questions of how far and to whom the "immanent frame" extends. Moreover, Taylor's account precludes an understanding of the role that religion continues to play in this secular age. Critics of his formulation argue that by not taking on board religious voices, a secular democratic public sphere fails in its promise of integration. The creative, ethical possibilities of this public sphere are lessened by not being informed by religion (Calhoun et al. 2011, 18).

Theorist of the liberal public sphere, Juergen Habermas, has been rethinking his neglect of religion (Habermas 2011; 2008). Habermas notes that the role of religion in society has not been resolved through secular political authority and laicism has not overcome the apparent paradox of having religious citizens in a secular society merely by privatizing religion: "as long as religious communities play a vital role in civil society and the public sphere, deliberative politics is as much a product of the public use of reason on the part of religious citizens as on that of nonreligious citizens" (Habermas 2011, 24). His "post-secular" position does not call for a return to a world of religious ideas or a reversal of the secularization of state power. Rather, religious traditions in a democratic society would have a bearing on public reason: their values could be translated into a universally acceptable language of ethics for religious and nonreligious citizens (Habermas 2011, 28). For Habermas, non-secular world views, as well as assertions of religious communities for political recognition, can exist within Taylor's immanent frame, for the resolution of religion in the public sphere must take place through this-worldly institutions and methods. Although Taylor and Habermas would part ways on an idea of public reason and Taylor disputes post-secularism as a viable intellectual position, they both seek just and plural solutions to the potential problem of religious diversity in liberal constitutional democracies, rather than a normative separation of religion and politics defining the public good. ${ }^{25}$

There are those post-secularists who argue for stepping outside the immanent frame altogether - modern categories of religion and secularism, the western individual subject and the liberal state are, themselves, the problem. Nandy, for instance, maintains that the imposition of such categories on societies like India where they have no cultural or historical foundation is a violent act in itself and will necessarily throw up more 
violence (Nandy 1988). This position, while possibly attractive to those who see modern knowledge as having colonized the minds of nonWestern peoples, leads to a philosophical and intellectual cul-de-sac: if one manages to escape modern categories, how does one know? ${ }^{26}$

This more recent scholarship allows us to reflect again on secularism in India. Much of the debate on secularism in India has taken its meaning for granted, relying on a reified idea of religion and defining it through its institutional separation from politics. Those who reject it as a framework for social organization still retain a normative understanding of "secularism" and "religion" as closed categories of modernity, in binary opposition. However, this preoccupation with religion-as-thing prevents us from understanding what it meant and who it was for in this context. To return to Taylor: "We think of 'secularism' as a selfsame process that can occur everywhere," he writes. "And we think of secularist regimes as an option for any country, whether or not they are actually adopted" (Taylor 2011b, 303). But while the words may be taken up, "do they really mean the same thing in each iteration? Are there not, rather, subtle differences which can bedevil cross-cultural discussion on these matters?" (Taylor 2011b, 303).

Both Taylor and Asad offer methodological approaches for understanding secularism. Each has emphasized the importance of genealogy in unearthing the specificity of historical experience which in turn elaborates the differences in meaning across contexts. In India, such an exercise reveals that "secularism" emerged as a category in political debate in the transition from nationalism to independence. The dominant idea in the constituent assembly debates was that the new state would be a liberal democracy whose people had privatized their religious affiliations and become citizens of the nation. Secularism in India thus shaped the nature of citizenship. Central to this was the protection of minorities. Self-styled representatives of religious minorities and the Scheduled Castes and Scheduled Tribes argued that Indian democracy should recognize the plurality of voices in a constitutional settlement. Bhargava would argue that the protection of minorities was one element of the "multivalue" system that constituted Indian secularism. Another was a state which intervened in the practices of religious communities to uphold values of equality. Certainly, these values of equality and plurality intersect with normative secularism in ways which allow us to recover secularism for India. But I would argue the point differently. Secularism in India at the point of its clearest articulation in the constituent assembly, in the very recognition by the state of its responsibility to protect its religious 
minorities, betrayed their dynamic potential. While liberal values of tolerance and protection of minorities is written into any idea of secularism, in India, secularism was defined through the rejection of religious minorities' claims on the state. What secularism in India denied, then, was the legitimacy of the place of the community in the nation. Methodologically, a study of the context in which this political term was given life in postindependence India, shows how secularism was defined in the particular.

\section{NOTES}

1. The phrase "a secular age" comes from Charles Taylor, whose book of the same title has prompted scholars across disciplines to revisit the question of secularism in European history and the contemporary world: see Taylor (2007). For commentary on this work, see Warner et al. (2010).

2. This is a position which was widely held by Indian nationalists and has been extensively reproduced in the post-independence period. See, Nehru (1946); Chatterji (1984); Esteves (1996); Engineer (2003). For critical analysis, see Upadhyaya (1992); Bhargava (1998); Khilnani (2002).

3. There is an important body of literature that has grown up around these issues. On Shah Bano, see Bajpai (2010, ch. 5); Menon (1998); Hasan (1989). On dalit Christianity and contemporary conversion movements, see Robinson and Kujur (2010) and Sarkar (1999). On reservations in government employment, see Bajpai (2010, ch. 6); Menon and Nigam (2007, ch. 1); Shah (2002).

4. By the time the constituent assembly sat, Untouchable and tribal communities were referred to as the Scheduled Castes (SCs) and Scheduled Tribes (STs), respectively. A list or "schedule" of these castes and tribes had been drawn up by region based on the 1931 Census and incorporated into the 1935 Government of India Act, the last constitutional reform before independence.

5. Dilip Menon has made a similar point about communalism: see Menon (2006).

6. Dharma is often translated as "religion" but more accurately translates as "duty" or "way."

7. Correspondence on Council Reform, Mss Eur 573 John Morley Papers, vol. 32 (October 1906August 1907), Oriental and India Office Collections (OIOC), British Library, London.

8. T. Morison's note on the "Scheme for Representation of the Principal Communities of Indian Society," proposed by Sir William Lee-Warner, April 18, 1907; Morley Papers, vol. 32.

9. Minto to Morley, March 21, 1907; Morley Papers, vol. 32.

10. Ibid.

11. Minto telegram October 5, 1908; Morley Papers, vol. 33 (October 1908-May 1909).

12. Bombay Presidency Association to the Government of Bombay, February 24, 1908 para. 12, public letter from India, 1908, vol. xxxvii, quoted in Wasti $(1964,162)$.

13. Oriental Review, para. 22 week ending January 14, 1905, Report on Native Newspapers for the Bombay Presidency.

14. Indian Social Reformer, November 4, 1906, week ending November 10, Report on Native Papers.

15. The separate electorate for non-confessional communities continued although, unlike those for religious minorities, were not controversial and rarely appeared in the debates on minority representation later.

16. On Ambedkar see Rao (2009); Jaffrelot (2005); Omvedt (1994); Gore (1993).

17. I use "depressed classes" and "Untouchables" interchangeably here. "Depressed classes" was the term used by the colonial government to refer to Untouchables.

18. Shastra is a general term referring to the large body of Hindu scriptures.

19. B.S. Moonje's Diaries and Letter Pads, reel 1, Nehru Memorial Museum and Library, New Delhi, October 7, 1931.

20. Indian Round Table Conference (second session), Proceedings, ninth sitting, October 8, 1931, 530; Moonje Diaries, October 8, 1931.

21. Taken from Pandit Govind Ballabh Pant's speech in the Constituent Assembly moving the Resolution. The term "backward classes" included the Scheduled Castes and Scheduled Tribes, but was a more ambiguous term and was not confined to them. This would become controversial later in the debates. 
22. See the debate on secularism in the constituent assembly, CAD, vol. VII, November 24, 1948, and Jha (2002).

23. Bajpai has explored in detail the process by which minorities lost their entitlement to reservations: Bajpai (2010, chs. 2, 3, 4); see also Tejani (2008, ch. 6).

24. The secularization thesis has been widely reconsidered: see, Warner (2010); Bruce (2002); Casanova (1994).

25. On Taylor's refuting that this is a post-secular age see Craig Calhoun $(2011,78)$ who calls the debate on post-secularism "a red herring."

26. On the inherent violence of secular knowledge: see, Chakrabarty (2000).

\section{REFERENCES}

All Parties Conference. 1975[1928]. The Nehru Report: An Anti-Separatist Manifesto. New Delhi: Michiko \& Panjathan.

Ambedkar, B.R. 1989. "Evidence before the Southborough Committee." In Dr. Babasaheb Ambedkar, Writings and Speeches, volume 1. Bombay: Education Department, Government of Maharashtra.

Ansari, Iqbal. 1999. "Minorities and the politics of constitution making in India." In Minority Identities and the Nation State, eds. D.L. Sheth and G. Mahajan. New Delhi: Oxford University Press.

Appadurai, Arjun. 1981. Worship and Conflict under Colonial Rule: A South Indian Case. Cambridge: Cambridge University Press.

Asad, Talal. 2003. Formations of the Secular: Christianity, Islam, Modernity. Stanford, CA: Stanford University Press.

Audard, C. 2011. "Rawls and Habermas on the Place of Religion in the Political Domain." In Habermas and Rawls: Disputing the Political, eds. J. Gordon Finlayson and F. Freyenhagan. Oxford: Routledge.

Bajpai, Rochana. 2010. Debating Difference: Minority Rights and Liberal Democracy in India. New Delhi: Oxford University Press.

Basu, Tapan, Pradip Datta, Sumit Sarkar, Tanika, and Sen S. Sarkar. 1993. Khaki Shorts and Saffron Flags: A Critique of the Hindu Right. New Delhi: Orient Longman.

Bhargava, Rajeev. 2010. The Promise of India's Secular Democracy. New Delhi: Oxford University Press.

Bhargava, Rajeev. 2007. "The distinctiveness of Indian Secularism." In The Future of Secularism, ed. T. N. Srinivasan. New Delhi: Oxford University Press.

Bhargava, Rajeev (ed). 1998. Secularism and its Critics. New Delhi: Oxford University Press.

Bhattacharya, Neeladri. 1996. "Remaking Custom: The Discourse and Practice of Colonial Codification." In Tradition, Dissent and Ideology: Essays in Honour of Romila Thapar, eds. R. Champakalakshmi and S. Gopal. New Delhi: Oxford University Press.

Bruce, Steve. 2002. God is Dead: Secularization in the West. Oxford: Blackwell.

Calhoun, Craig, Mark Juergensmeyer, and Jonathan VanAntwerpen (eds). 2011. Rethinking Secularism. New York, NY: Oxford University Press.

Calhoun, Craig. 2011. "Secularism, Citizenship and the Public Sphere." In Rethinking Secularism, eds. Craig Calhoun, Mark Juergensmeyer, and Jonathan VanAntwerpen. New York, NY: Oxford University Press, 75-91.

Carroll, Lucy. 1983. "Law, Custom, and Statutory Social Reform: The Hindu Widows' Remarriage Act of 1856." Indian Economic \& Social History Review 20:363-388.

Casanova, Jose. 2011. "The secular, Secularizations, Secularisms." In Rethinking Secularism, eds. Craig Calhoun, Mark Juergensmeyer, and Jonathan VanAntwerpen. New York, NY: Oxford University Press, 54-74. 
Casanova, Jose. 1994. Public Religions in the Modern World. Chicago, IL: University of Chicago Press.

Chakrabarty, Dipesh. 2000. Provincializing Europe: Postcolonial Thought and Historical Difference. Princeton, NJ: Princeton University Press.

Chandhoke, Neera. 1999. Beyond Secularism: The Rights of Religious Minorities. New Delhi: Oxford University Press.

Chatterjee, Partha. 1994. "Secularism and Toleration." Economic and Political Weekly 29:1768-1777.

Chatterji, P.C. 1984. Secular Values for Secular India. New Delhi: Lola Chatterji.

Chiriyankandath, James. 2000. "Creating a Secular State in a Religious Country: The Debate in the Indian Constituent Assembly." Commonwealth and Comparative Politics 38:1-24.

Copland, Ian. 2010. "What's in a name? India's tryst with secularism." Commonwealth and Comparative Politics 48:123-147.

Engineer, A.A. 2003. Communal Challenge and Secular Response. Delhi: Shipra.

Esteves, Sarto. 1996. Nationalism, Secularism, Communalism. Delhi: South Asia Publications.

Habermas, Juergen. 2011. "The political, the Rational Meaning of a Questionable Inheritance of Political Theology." In The Power of Religion in the Public Sphere, eds. E. Mendieta and J. VanAntwerpen. New York, NY: Columbia University Press.

Habermas, Juergen. 2008. Between Naturalism and Religion: Philosophical Essays (transl. Ciaran Cronin). Cambridge: Polity Press.

Hasan, Zoya. 1989. "Minority identity, Muslim Women Bill Campaign and the Political Process." Economic and Political Weekly 24:44-50.

Gopal, Sarvepalli. 1993. Anatomy of a Confrontation: The Rise of Communal Politics in India. London: Zed Press.

Gore, M.S. 1993. The Social Context of an Ideology: Ambedkar's Political and Social Thought. New Delhi: Sage.

Jaffrelot, Christophe. 2005. Dr Ambedkar and Untouchability: Fighting the Indian Caste System. New York, NY: Columbia University Press.

Jakobsen, Janet R., and Ann Pellegrini. 2008. Secularisms. Durham, NC: Duke University Press.

Jha, Shefali. 2002. "Secularism and the Constituent Assembly Debates, 1946-1950." Economic and Political Weekly 37:3175-3180.

Jha, Shefali. 2003. "Rights versus Representation: Defending Minority Interests in the Constituent Assembly." Economic and Political Weekly 38:1579-1583.

Khilnani, Sunil. 2002. "Nehru's Faith.” Economic and Political Weekly 37:4793-4799.

Kumar, Ravinder. 1985. "Gandhi, Ambedkar and the Poona Pact, 1932." South Asia 8:87101.

Luthera, Ved Prakash. 1964. The Concept of the Secular State and India. London: Oxford University Press.

Madan, T.N. 1987. "Secularism in its Place." Journal of Asian Studies 46:747-759.

Mahmood, Saba. 2011. "Can Secularism be Other-wise?" In Varieties of Secularism in a Secular Age, eds. M. Warner, J. VanAntwerpen, and C. Calhoun. Cambridge, MA: Harvard University Press.

Mendus Susan (ed). 1988. Justifying Toleration: Conceptual and Historical Perspectives. Cambridge: Cambridge University Press.

Menon, Dilip. 2006. The Blindness of Insight: Essays on Caste in Modern India. Pondicherry: Navayana Pub.

Menon, Nivedita, and Aditya Nigam. 2007. Power and Contestation: India since 1989. Hyderabad: Orient Longman. 
Mitchell, Timothy. 2000. "The Stage of Modernity." In Questions of Modernity, ed. T. Mitchell. Minneapolis, MN: University of Minnesota Press.

Nandy, Ashis. 1997. "The Twilight of Certitudes: Secularism, Hindu Nationalism and other Masks of Deculturation." Alternatives 22:157-176.

Nandy, Ashis. 1988. "The Politics of Secularism and the Recovery of Religious Tolerance." Alternatives 13:2.

Nehru, Jawaharlal. 1946. The Discovery of India. New York, NY: John Day.

Nigam, Aditya. 2006. The Insurrection of Little Selves: The Crisis of Secular-Nationalism in India. New Delhi: Oxford University Press.

Omvedt, Gail. 1994. Dalits and the Democratic Revolution: Dr Ambedkar and the Dalit Movement in Colonial India. New Delhi: Sage.

Parekh, Bhikhu. 1989. Gandhi's Political Philosophy: A Critical Examination. Basingstoke: Macmillan.

Pecora, Vincent. 2006. Secularization and Cultural Criticism: Religion, Nation and Modernity. Chicago, IL: University of Chicago Press.

Puri, B.N. 1990. Secularism in Indian Ethos. Delhi: Atma Ram and Sons.

Rao, Anupama. 2009. The Caste Question: Dalits and the Politics of Modern India. Berkeley, CA: University of California Press.

Robinson, Rowena, and Joseph Marianus Kujur (eds). 2010. Margins of Faith: Dalit and Tribal Christianity in India. Los Angeles, CA: Sage.

Sarkar, Sumit. 1999. "Conversions and Politics of the Hindu Right." Economic and Political Weekly 34:1691-1700.

Sarkar, Sumit. 1994. "The Anti-Secularist Critique of Hindutva: Problems of a Shared Discursive Space." Germinal 1, Journal of the Department of Germanic and Romance Studies, Delhi University.

Shah Ghanshaym (ed). 2002. Caste and Democratic Politics in India. Delhi: Permanent Black.

Shiva Rao, B. 1967. The Framing of India's Constitution, Select Documents Volume II. Delhi: Indian Institute of Public Administration.

Smith, D.E. 1963. India as a Secular State. Princeton, NJ: Princeton University Press.

Talreja, K.M. 1996. Pseudo-secularism in India. Mumbai: Rashtriya Chetana Prakashan.

Tambiah, S.J. 1998. "The Crisis of Secularism in India”, in R. Bhargava (ed), Secularism and its Critics. New Delhi: Oxford University Press.

Taylor, Charles. 2011a. "Why We Need a Radical Redefinition of Secularism." In The Power of Religion in the Public Sphere, eds. Eduardo Mendieta and Jonathan VanAntwerpen. New York, NY: Columbia University Press and S.S.R.C.

Taylor, Charles. 2011b. "What Does Secularism Mean?" In Dilemmas and Connections, Selected Essays, ed. C. Taylor. Cambridge, MA: Harvard University Press.

Taylor, Charles. 2007. A Secular Age. Cambridge, MA: Harvard University Press.

Tejani, Shabnum. 2008. Indian Secularism: A Social and Intellectual History, 1890-1950. Bloomington, IN: Indiana University Press.

Upadhayaya, Prakash Chandra. 1992. "The Politics of Indian Secularism." Modern Asian Studies 26:815-853.

Verma, H.S. 1990. "Secularism: Reflections on Meaning, Substance and Contemporary Practice." In Secularism and Indian Polity, ed. Bidyut Chakrabarty. New Delhi: Segment.

Warner, Michael, Jonathan VanAntwerpen, and Craig Calhoun (eds). 2011. Varieties of Secularism in a Secular Age. Cambridge, MA: Harvard University Press.

Wasti, Syed Reza. 1964. Lord Minto and the Indian National Movement, 1905-1910. Oxford: Clarendon.

Warner, Rob. 2010. Secularization and its Discontents. London: Continuum. 